\title{
Digital Data from the Great Sand Dunes Airborne Gravity Gradient Survey, South-Central Colorado
}

By B.J. Drenth, J.D. Abraham, V.J.S. Grauch, V.F. Labson, and G. Hodges

Open-File Report 2013-1011

U.S. Department of the Interior

U.S. Geological Survey 


\section{U.S. Department of the Interior \\ KEN SALAZAR, Secretary}

\section{U.S. Geological Survey \\ Marcia K. McNutt, Director}

U.S. Geological Survey, Reston, Virginia: 2013

For more information on the USGS-the Federal source for science about the Earth, its natural and living resources, natural hazards, and the environment-visit http://www.usgs.gov or call 1-888-ASK-USGS

For an overview of USGS information products, including maps, imagery, and publications, visit http://www.usgs.gov/pubprod

To order this and other USGS information products, visit http://store.usgs.gov

Suggested citation:

Drenth, B.J., Abraham, J.D., Grauch, V.J.S., and Hodges, G., 2013, Digital data from the Great Sand Dunes airborne gravity gradient survey, south-central Colorado, U.S. Geological Survey Open-File Report 2013-1011, $5 \mathrm{p}$.

Any use of trade, product, or firm names is for descriptive purposes only and does not imply endorsement by the U.S. Government.

Although this report is in the public domain, permission must be secured from the individual copyright owners to reproduce any copyrighted material contained within this report. 


\section{Contents}

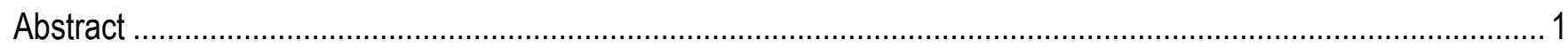

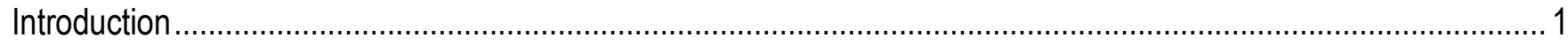

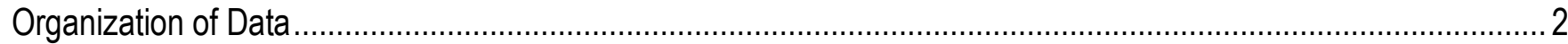

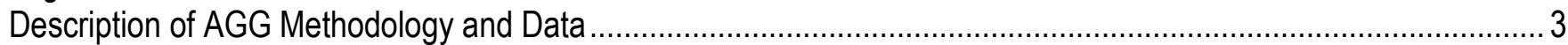

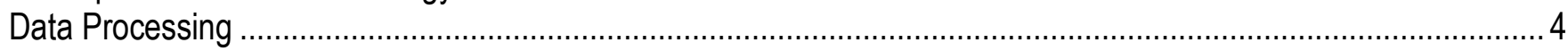

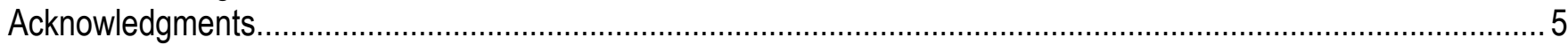

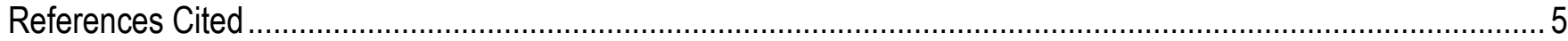

\section{Figures}

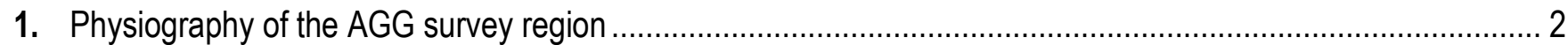

2. Components of the Earth's gravitational field ................................................................................. 3 


\title{
Digital Data from the Great Sand Dunes Airborne Gravity Gradient Survey, South-Central Colorado
}

\author{
By B.J. Drenth, ${ }^{1}$ J.D. Abraham, ${ }^{1}$ V.J.S. Grauch, ${ }^{1}$ V.F. Labson, ${ }^{1}$ and G. Hodges ${ }^{2}$
}

\begin{abstract}
This report contains digital data and supporting explanatory files describing data types, data formats, and survey procedures for a high-resolution airborne gravity gradient (AGG) survey at Great Sand Dunes National Park, Alamosa and Saguache Counties, south-central Colorado. In the San Luis Valley, the Great Sand Dunes survey covers a large part of Great Sand Dunes National Park and Preserve.
\end{abstract}

\section{Introduction}

This report describes data collected from a high-resolution airborne gravity gradient (AGG) survey flown over a portion of Great Sand Dunes National Park and Preserve in the San Luis Valley of south-central Colorado (fig. 1). The survey covers the majority of the sand dunes themselves, as well as an area south of the dunes. Two different, yet partially overlapping, survey areas were flown using different specifications so that the effects of different line spacing and terrain clearance on the data could be discerned and directly compared (fig. 1). The survey was flown in February 2012, by Fugro Airborne Surveys Corp., on contract to the U.S. Geological Survey (USGS).

Scientific objectives of the AGG survey are to investigate the subsurface structural framework that may influence groundwater hydrology and seismic hazards, and to investigate AGG methods and resolution using different flight specifications. Funding was provided by an airborne geophysics training program of the U.S. Department of Defense's Task Force for Business \& Stability Operations. The choice of survey area coincides with the goals of an ongoing USGS project called "Geologic Framework of Rio Grande Basins." The project's overall goal is to understand the subsurface geologic framework of the San Luis basin in order to improve regional groundwater models.

\footnotetext{
${ }^{1}$ U.S. Geological Survey

${ }^{2}$ Fugro Airborne Surveys Corp.
} 


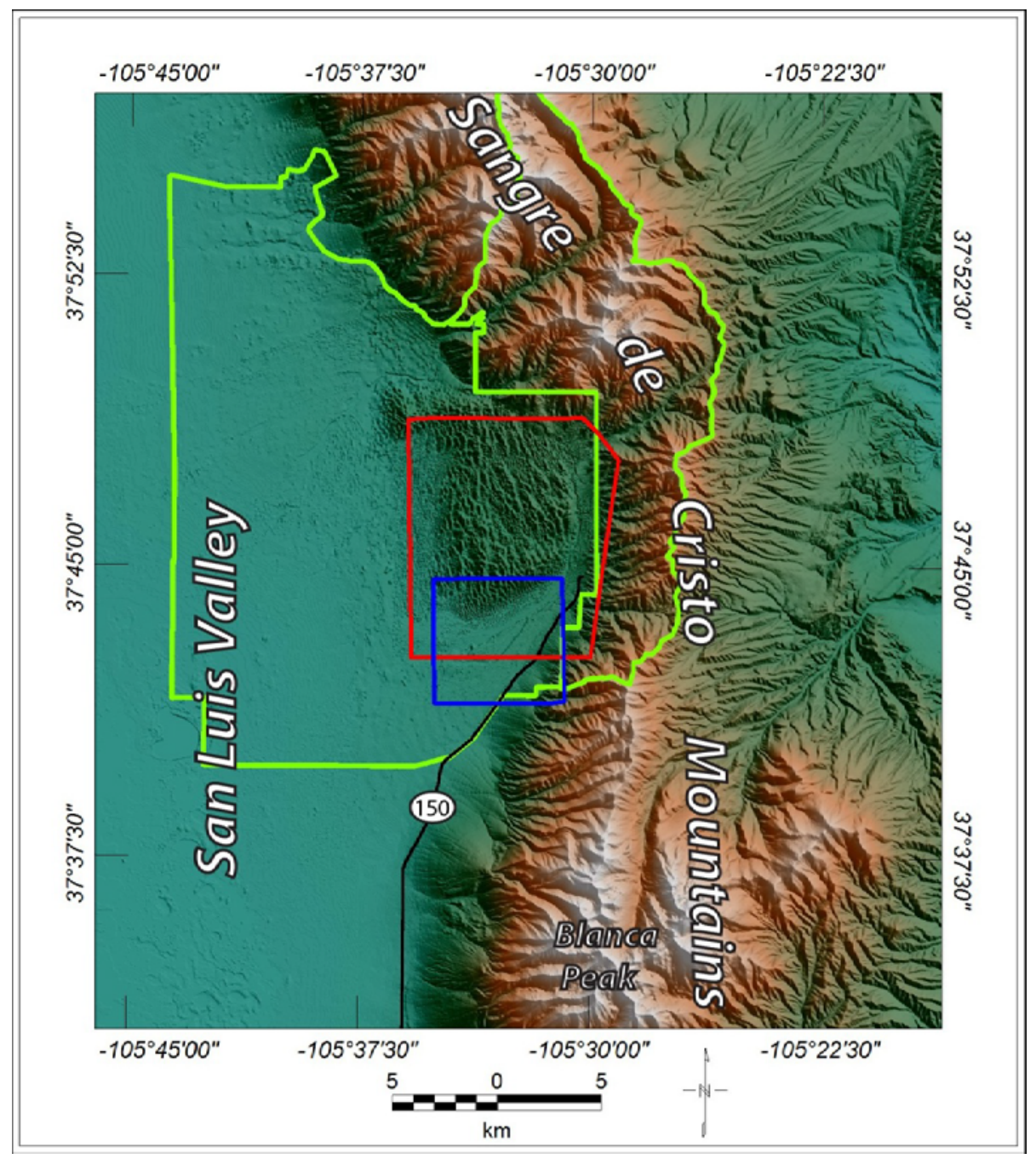

Figure 1. Physiography of the AGG survey region. Green polygon is Great Sand Dunes National Park and Preserve boundary. Red polygon shows survey area 1, flown with $100 \mathrm{~m}$ spaced lines at a nominal terrain clearance of $80 \mathrm{~m}$. Blue polygon shows survey area 2, flown with $50 \mathrm{~m}$ spaced lines at a nominal terrain clearance of $40 \mathrm{~m}$.

\section{Organization of Data}

The AGG data are presented mainly as linedata in ASCII and Geosoft database formats, with a separate file for each survey area (see "linedata" folder). There are also Grid Exchange Format grids (see "grids" folder) of vertical gradient data for each survey area, with and without terrain corrections of 2.67 grams per cubic centimeter $(\mathrm{g} / \mathrm{cc})$ density, and AGG data merged and conformed with ground gravity (see below). 


\section{Description of AGG Methodology the Data}

AGG data are collected using airborne gradiometers that measure subtle variations in the Earth's gravitational field. Fugro's FALCON gradiometer system was used for this survey (appendix). Conventional gravity measurements deal with $\mathrm{g}_{\mathrm{z}}$, or the vertical component of the acceleration due to gravity (fig. 2). Measurements are taken with gravity meters on the ground (normally) or from aircraft, although the latter is problematic because gravity meters cannot distinguish between accelerations due to density variations (such as geology) and aircraft accelerations. On the other hand, gravity gradient measurements deal with the full tensor representing the gradient of Earth's gravitational field and are more suitable to airborne surveying because aircraft accelerations are largely cancelled out.

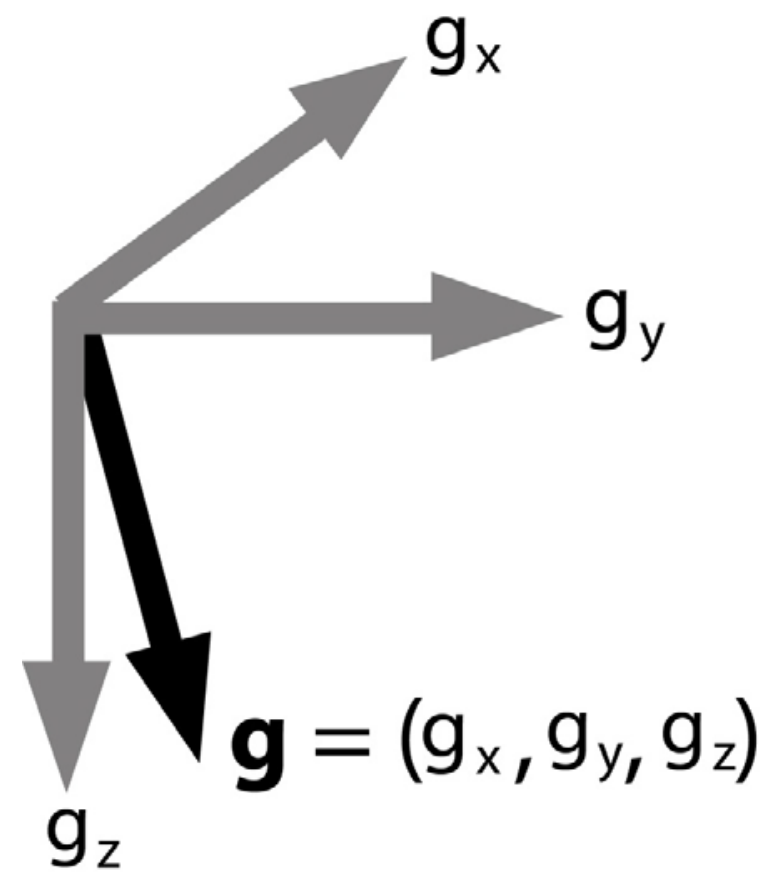

Figure 2. Components of the Earth's gravitational field. X-and $y$-directions are horizontal east and north, respectively.

In the nomenclature used for Fugro's FALCON system, the full gravity gradient tensor can be expressed as:

$$
G=\left[\begin{array}{lll}
\frac{\partial g_{x}}{\partial x} & \frac{\partial g_{x}}{\partial y} & \frac{\partial g_{x}}{\partial z} \\
\frac{\partial g_{y}}{\partial x} & \frac{\partial g_{y}}{\partial y} & \frac{\partial g_{y}}{\partial x} \\
\frac{\partial g_{z}}{\partial x} & \frac{\partial g_{z}}{\partial y} & \frac{\partial g_{z}}{\partial z}
\end{array}\right]=\left[\begin{array}{lll}
G n n & \text { Gne } & \text { Gnd } \\
\text { Gen } & \text { Gee } & \text { Ged } \\
\text { Gdn } & \text { Gde } & \text { Gdd }
\end{array}\right]
$$

where $\mathrm{G}$ is the gradient tensor, and $\mathrm{g}$ is gravity (fig. 2).

However, the tensor is simpler than it appears because: 
Gnn + Gee + Gdd $=0 \quad$ (Laplace's equation)

Gne $=$ Gen

Gnd $=G d n$

Ged $=$ Gde

Thus, only five gradients (or components) are independent. While some AGG systems currently being flown measure each independent tensor component, the FALCON system measures two horizontal components, and those data are used to calculate the full tensor after the survey is flown (appendix).

The AGG survey employed a helicopter and was split up into two separate, yet partially overlapping blocks (fig. 1). Area 1 was flown along traverse lines spaced 100 meters (m) (about 328 feet [ft]) apart and oriented east-west, with a nominal terrain clearance of $80 \mathrm{~m}$ (about $262 \mathrm{ft}$ ). Northsouth tie lines were flown at a spacing of 1,000 m (about 3,280 ft). Area 2 was flown along traverse lines spaced $50 \mathrm{~m}$ (about $164 \mathrm{ft}$ ) apart and oriented east-west, with a nominal terrain clearance of $40 \mathrm{~m}$ (about $131 \mathrm{ft}$ ). North-south tie lines were flown at a spacing of $500 \mathrm{~m}$ (about 1,640 ft). Deviations from the nominal terrain clearances were made to allow for safe and smooth flight over rough topography. The orientation of traverse lines was chosen to be oblique to the predominant geologic strike of the area. The two flight areas were chosen to partially overlap so that data collected with different line spacing and terrain clearance could be directly compared, as part of ongoing USGS research on AGG data, methods, and survey design.

\section{Data Processing}

Contractor-provided details of the flight specifications, survey procedures, and data processing are included in the appendix. The flight-line data from the contractor are also included in this report. Gridded data are not included, except for the airborne gravity data that have been merged and conformed with ground gravity data.

In principle, AGG data can easily be transformed to gravity field data using integration. However, AGG data do not have strong resolution in the longer wavelengths, because the measurement of gradients inherently emphasizes the shorter wavelengths. Longer wavelengths of the gravity field from conventional ground gravity measurements can be used to replace the longer wavelengths from AGG data in a process called conforming (Dransfield, 2010). Conforming involves low-pass filtering of ground gravity data, high-pass filtering of airborne gravity data, and adding the results to make a gravity grid that ideally includes all wavelengths of interest. The low-pass and high-pass filters are selected such that (1) there are no missing wavelengths (the filters have the same roll-off distance), and (2) the filter cutoff distances are most appropriate for the given datasets. By default, the contractor uses filters that roll-off between $15 \mathrm{~km}$ and 10 kilometers $(\mathrm{km})$ (appendix). In other words, the ground gravity data are low-pass filtered with a filter that rolls off to zero between 15 and $10 \mathrm{~km}$, and the airborne gravity are high-pass filtered with a filter that rolls to zero between 10 and $15 \mathrm{~km}$.

In this case, distance cutoffs shorter than 10 and $15 \mathrm{~km}$ are reasonable, because there is reasonable ground gravity coverage, and the AGG survey is only 6-km wide (area 2) at its smallest. Therefore, the conforming process described by Dransfield (2010) was used, although the filters were designed to roll off between 6 and $4 \mathrm{~km}$ instead of 15 and $10 \mathrm{~km}$. The resulting grid (see "grids" folder) is conformed_gravity_2p67.gxf.

Prior to conforming, the contractor-provided airborne gravity $(\mathrm{gD})$ grids were downward continued to the ground surface, regridded to a coarser grid spacing of $100 \mathrm{~m}$, and merged. The "chessboard" continuation method of Cordell (1985), as implemented by Oasis montaj was used. In this 
method, the continued data are extrapolated from a series of parallel continuation surfaces that have each been computed using standard fast Fourier transform (FFT) techniques. The grid of radar-altimeter values determined the distances to downward continue the data to the ground. A low-pass filter was applied during downward continuation based on a cosine-squared roll-off function that increases the wavelength cutoff with greater continuation distance. The wavelength cutoff is inversely proportional to the continuation distance. High-cut factors of 2 for area 1 and of 3 for area 2 were applied to reduce high-frequency noise produced by downward continuation. The magnitude of the high-cut factors are only meaningful within the context of Oasis montaj, although the greater the value, the greater the amount of high-frequency noise suppression.

\section{Acknowledgments}

Great Sand Dunes National Park and Preserve staff, particularly Andrew Valdez and Fred Bunch, provided friendly and professional assistance during survey planning and execution. Mark Dransfield of Fugro gave critically important advice on survey planning and data processing at multiple stages of this work. Maureen Corbett at the USGS nimbly handled several unexpected and complex contractual issues prior to the survey starting.

\section{References Cited}

Cordell, Lindrith, 1985, Techniques, applications, and problems of analytical continuation of New Mexico aeromagnetic data between arbitrary surfaces of very high relief, in International Meeting on Potential Fields in Rugged Topography, Proceedings: Institute of Geophysics, University of Lausanne, Switzerland, Bulletin no. 7, p. 96-101.

Dransfield, Mark, 2010, Conforming Falcon gravity and the global gravity anomaly: Geophysical Prospecting, v. 58, p. 469-483. 